countries. They have become widely disseminated in Sweden and Norway, and there are now control associations in Finland, Russia, Germany and Scotland. In most places an attempt is made to carry out the weighing and valuation of the feed, as in Denmark; but, in some parts of Norway, where the cows subsist entirely on grass in the summer and on hay and straw in the winter, it is thought that the estimate of the feed will be too inaccurate, and therefore the work of the control assistant is limited to managing the test milking, testing for butter fat, and keeping a record of the milk and butter yield.

Where there is no record of the consumption of feed, there will be no basis for a fair comparison of the milk and butter yield in the various herds, because the amount of feed will always affect the yield of butter; but, even without a record of the feeding, the "control" will give every farmer valuable information regarding the yield of milk and butter of the individual cows, so that he can positively distinguish the best, the good, and the poor cows; and he gets an opportunity to find those cows that give particularly rich milk, which is of immense importance, if it is, as we believe, that giving rich or poor milk is for each cow a peculiar and inherited quality.

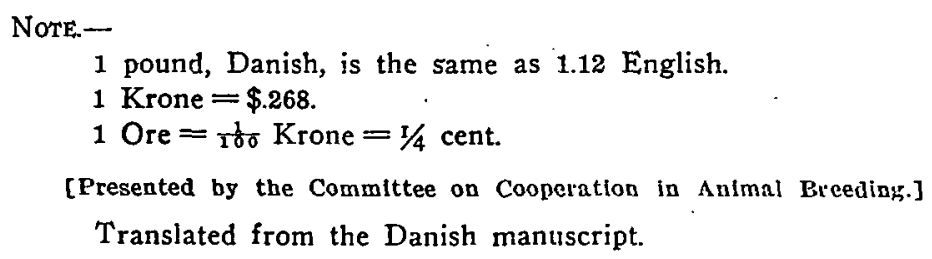

\title{
COW-TESTING ASSOCIATIONS.
}

\author{
Colon C. LIILIE, Coopersville, Mich.
}

A cow-testing association is a cooperative business association among the dairy farmers of a community for the purpose of testing their cows for economical production. Each cow is charged with the food she consumes and given credit for the butter fat she produces for the entire year at market prices. A competent person is employed by the association to go from farm to farm and weigh and compute the ration, weigh and test the milk and keep accurate records of the same. 
ORIGIN AND DEVELOPMENT.

The first cooperative cow-testing association was organized in Denmark in 1895. A dairy farmer, Mr. Hansen, had been weighing and testing the milk of his cows for a considerable length of time for the purpose of ascertaining which cows did not produce a profit. He found the work very satisfactory and, at Mrs. Hansen's suggestion, a meeting of the neighbors was called and it was there proposed that the work be extended to the neighborhood in a cooperative way, and through the influence of Mrs. Hansen the first cooperative cow-testing association was organized. This idea spread rapidly through Denmark, Sweden, Norway, Germany, and Finland. At the present time Denmark has over 500 cooperative associations, Sweden over 400 , and Sweden, Norway, Germany, and Finland. At the present time Dennumbers. The Danish and Swedish governments aid the dairymen by giving them moderate financial assistance to help pay the salary of the cow testers.

\section{HISTORY OF MOVEMENT IN THIS COUNTRY.}

The first cooperative cow-testing association in America was formed at Fremont, Newaygo County, Mich., in 1.905. We are indebted to Mr. Helmer Rabild, now in charge of cow-testing association work for the Dairy Division of the U. S. Department of Agriculture, for this idea of cooperation in testing cows. Mr. Rabild was at that time an inspector of the Dairy and Food Department of the State of Michigan, and was very much interested in dairy development. $\mathrm{He}$ is a Dane; having been born and brought up on a Danish dairy farm. His father belonged to a cooperative cow-testing association, so that he understood well all the details of the work, and he appreciated what the work was doing for his countrymen in Denmark, and was very enthusiastic about having the idea introduced into this country. It was through Mr. Rabild's work that the first association was organized at Fremont, under the auspices of the Michigan State Dairy and Food Department. Since then several organizations have been completed. At the present time we have five in actual operation. Chief Webster of the Dairy Division at Washington became interested in this idea of cooperative cow-testing associations, and took $\mathrm{Mr}$. Rabild away from Michigan and gave him a broader field. Since Mr. Rabild has been with the Department of Agriculture he has succeeded in organizing cooperative associations in several different States. 
Wisconsin has more than any other State at the present time. So far, no financial State aid has been given to this work in this country and it ought not to be necessary ever to give it. Each association ought to be self-supporting. The dairy farmer does not need financial help.

PRAC'TICAL WORKINGS OF THE ASSOCIATIONS.

The organization of a cow-testing association is a very simple business proposition. The dairy farmers of a community realizing the benefit to be derived from such an organization simply get together and organize, electing a president, a vice-president, a secretary, and a treasurer from their members. Ustually an executive committee is also elected, and the officers, with the executive committee, are given power to hire a man to do the testing. The tester is usually paid so much per cow, each member paying pro-rata. If there are 500 cows in the association, and the price fixed upon is $\$ 1$ per cow, then the tester receives $\$ 500$ for the year, and of course his board and lodging, because he goes from house to house, "boards around" as it were. If one man owns a herd of 25 cows, he pays $\$ 25$ toward the wages of the tester. If he owns 10 cows, he only pays $\$ 10$.

THE WORK OF THE TESTER.

The tester goes from farm to farm, visiting each farm at least once a month. Only about 26 herds can be tested in one organization, because as a rule the tester can only visit one farm each day. He arrives in the afternoon, sees the milking done, weighs the milk and records it in a book for the purpose. He takes a sample of the milk, sees the feeding done, weighs the ration, computes its value at market prices, charges each cow with the food consumed. Again in the morning he does the same thing. Then he tests the milk for butter fat and gives each cow credit for the number of pounds of butter fat produced at the market price. He estimates the yield of the cow and also the total value of the ration for a half month back and a half month to come, and records the amount in one lump sum. In Michigan the blanks and record books are furnished free by the State Dairy and Food Department. In Wisconsin I understand they are furnished by the State Dairymen's Association. The cow tester leaves a copy of his records with each farmer each month, after having recorded them in his regular book. He furnishes the record of each cow and also a summary of the whole herd, so that the farmer not only knows what each individual cow in his herd is doing, but also what the herd as 
a whole is doing. In Michigan, books for the cow tester contain enough sheets for each individual of each herd, and also for the monthly summary of each herd. Then sheets enough are bound into one little pamphlet-like book to be left with each member of the association so that his sheets are kept intact.

In Michigan so far, this work has been compiled at the end of the year and published in bulletin form; and, so far as I know, this is the only printed record of cow-testing associations in the United States. These bulletins can be obtained from the Dairy and Food Department, Lansing, Mich.

BENEFITS TO BE DERIVED.

First. This work has proved to our dairy farmers that it is more profitable to feed the crops produced on their farms to their cows than it is to sell them in the open market, at market prices. They realize that by feeding the crops they are receiving a cash income distributed throughout the year and that live-stock maintains and even improves the fertility of their farms. Many dairymen have believed that their profits are no larger than they would be if the feed were sold from their farms. These associations are proving the contrary. The members of four associations in Michigan in 1907 with upwards of 1,200 cows, in four different parts of the State, according to the records, received $\$ 1.85$ for every dollar's worth of feed which was fed to their cows. With such proof as this, dairymen are better satisfied with their business than before.

Second. Farmers are figuring now on more economical and better balanced rations. They are building more silos, and thinking about the subject where before little thought was given. This is one of the important results of keeping records of just exactly what the individuals of each herd. are doing.

Third. Farmers are selecting better sires and mating them with their profitable cows. The Fremont association, for instance, the first year had only one registered sire owned by its members, but at the present time they have 22 , which shows that the work of the cooperative cow-testing association has aroused interest in better breeding of dairy cows.

Fourth. Cows that will not show a profit are being fattened and sold to the butchers. The result is, increased net profit in the business. This accounts, in my estimation, in part at least, for the fact that the increase in production of butter is so slight at the present time. 
Farmers all over the country are keeping better track of their cows and are getting rid of poor cows. Their profits are increased, but the total production is decreased.

Fifth. Cooperation in breeding by the exchange of sires of proved quality and prepotency is sure to be one of the great results obtained by cooperative cow-testing associations. It is a well known fact that many of the best bulls of this country are slaughtered before their worth is really known. They are owned by individual farmers and, to prevent inbreeding, they are sold when young and a new bull is purchased. With cooperation among the farmers of a neighborhood, these bulls can be exchanged by neighbors, and when a bull is found which proves an especially valuable sire of high yielding females, he can be kept as long as he is useful. In my opinion this will be one of the greatest results which will eventually come from cooperation in the testing of dairy cows.

Sirth. Just as soon as the farmer realizes the amount to be gained by careful feeding of dairy cows, his interest will be aroused in the careful feeding and rearing of his young cattle, his hogs, etc. Very few dairymen at the present time can tell whether it pays to fatten dry or barren cows, or cows which are past their usefulness for dairy purposes, or whether it would pay to sell them at once without putting any more feed into them, simply because they have never kept track of the feed. Now, the cow tester is going to be able to tell the owners just how much it costs to produce a pound of beef upon a discarded dairy cow. So, too, he will figure economical rations for the growing of his young stock, also for the fattening of his hogs. Very few farmers of this country know how much it costs to produce a pound of pork, simply because they have never kept track of the feed. The cow tester comes to the farm every month in the year and can carefully estimate the amount of food consumed by the hogs. He can assist the farmer in preparing an economical ration for hogs and for young stock just as well as for the cows themselves, and this is bound to prove a very interesting and profitable feature of cowtesting associations.

\section{INCREASEDD YIELDS.}

This work has not progressed long enough in this country to furnish sufficient data to draw definite conclusions with regard to increased yields; but in Denmark wonderful results have been obtained. In 1894 the average yield of butter fat per cow was 100 
pounds per annum, and in 1903, eight years after the organization. of the cow-testing associations, it had increased to 212 pounds per cow, or an increase of over 100 per cent. The increase will show the second year in a cow-testing association if the poor cows are turned off at the end of the first year; but it will show better later on when heifers have been reared from the most profitable cows bred to good dairy sires.

Cow-testing associations place dairying on a business basis. The dairyman knows exactly what he is doing. He sees the effect of proper rations, proper care, and judicious selection and breeding upon his herd, and acts accordingly. As an inevitable result, there will be a material decrease in the cost of production which will place dairy farming on a much more profitable basis.

\section{MAINE COOPERATIVE BREEDERS' ASSOCIATIONS.}

B. WALKER MCKEEN, Fryburg, $M c$.

Maine has become the leading dairy State of the East. This has been brought about largely through cooperative effort. The latest development in this direction is the formation of cooperative breeders. associations for the purpose of encouraging and facilitating the growing of thoroughbred and high-grade dairy stock.

The general plan of these associations is as follows:

A community of farmers covering as large an area as can be conveniently reached from a central point, interested in the improvement of some one breed of cattle, bind themselves by an agreement to do everything possible to advance the interests of that breed, and to use only registered sires. A preliminary meeting is called, an association formed with capital stock sufficient to purchase the number of sires necessary for the number of cows represented, with a balance for current expenses. Officers consisting of president, secretary, treasurer, agent, auditor, and executive committee are elected and the necessary incorporations effected. The breeding. males are then purchased from among the best herds of the breed represented, and become the property of the association.

They are then placed at convenient.distances, in order to have each animal within as easy reach as possible of his proportion of the cows. - These males are used on the herds of the members of the association, regardless of whether the cows are thoroughbreds or 